\title{
Knowledge of and attitudes towards extending professional powers among departmental nurses with respect to issuing prescriptions and independent referring for diagnostic tests - preliminary report
}

\begin{abstract}
Introduction. An independent prescribing certain drugs, including issuing prescriptions, as well as an entitlement to refer patients for certain diagnostic tests, constitute the key competences of an advanced nurse/midwife practice.

Aim. To analyze knowledge and attitudes of departmental nurses (DN) towards extending professional powers of nurses and midwives.

Material and methods. The sample involved 23 DN (women: 100\%) working in the Independent Public Children's Teaching Hospital in Warsaw. The mean age was 49 years (mode and median: 50; min. 31, max. 61, SD=7.95). The mean of professional experience was 30 years (mode: 25 , median: 30 , min. 17 , max. 40, $\mathrm{SD}=6.38$ ). A voluntary and anonymous questionnaire with 10 questions referring to knowledge and 32 statements concerning attitudes evaluated in the Likert scale was conducted.

Results. Almost all DN knew that prescribing drugs is a right and not an obligation. Nearly half of the DN knew when the new regulations shall enter into force. DN believed that the new regulations shall improve patient care and increase patient's comfort and access to services. DN concern about preparation of nurses and midwives for new competences.

Conclusions.

1. The study group's level of knowledge about the new competences was insufficient and requires supplementing.

2. The attitudes of the study group towards the new competences were not unambiguous. It should, however, be noted that the study was conducted in a specialized children's teaching hospital, where the application of the amended regulations is limited.

3. Although the nursing management staff supports the legislative changes, they object to the process of introducing them. This applies particularly to the necessity of an adequate preparation of nurses and midwives.

4. The study should be continued among a representative group of nurses with a similar level of education, professional experience, and place of work, with particular consideration of nurses working in the outpatient health care.
\end{abstract}

Keywords: amendment, new competences, prescription of drugs, prescriptions, diagnostic tests, nurses and midwives.

DOI: $10.1515 /$ pjph-2017-0012

\section{INTRODUCTION}

The possibility of prescribing certain drugs independently, including issuing prescriptions, as well as entitlement to refer patients for certain diagnostic tests constitute the key competences of an advanced nurse/midwife practice in a number of countries [1]. She or he is actively involved in treatment and becomes an independent healthcare provider (nurse practitioner) in particular situations. This model has been introduced in many Anglo-Saxon and Western European countries, e.g. the United Kingdom, Finland, Spain, and Canada [2].

The Polish Parliament has also decided to extend the competences of particular groups of nurses and midwives. Article 15a of the Nurses and Midwives Act says that each nurse or midwife with a Bachelor's degree or specialisation will be allowed to issue prescriptions for medications under a medical order. In addition, nurses and midwives with a Master's degree or specialisation will be allowed to prescribe certain medications independently and write prescriptions for them. These two powers will be granted only to those nurses and midwives who completed a specialist course.

An amendment to the Nurses and Midwives Act gives nurses and midwives with a Bachelor's degree or specialisation, the authority to refer patients for particular diagnostic tests. A list of these tests as well as a list of medications nurses and midwives will be allowed to prescribe on their own will be included in a Regulation of the Minister of Health. These changes will enter into force on 1st January 2016 [3].

The provisions aim to increase the availability of healthcare services, particularly at lower referral levels, as well as to enhance the prestige of the nursing and midwifery professions [4].

Providing doctors, patients, as well as nurses and midwives in the first place with sufficient information about the proposed changes is of key importance to the success of the reform. A positive attitude of nurses and midwives towards the changes

\footnotetext{
${ }^{1}$ Division of Teaching and Outcomes of Education, Faculty of Health Sciences, Medical University of Warsaw, Poland

${ }^{2}$ Student Research Society for Medical Law, Warsaw Medical University, Poland

${ }^{3}$ Independent Public Children's Teaching Hospital in Warsaw, Poland
} 
may also be important. Otherwise, the new law may become a "dead" law and its objectives will not be achieved.

\section{AIM}

The study aimed to analyse the knowledge and attitudes of departmental nurses towards extending their professional powers with respect to issuing prescriptions and referring for diagnostic tests on their own.

\section{MATERIAL AND METHODS}

The study included 23 departmental nurses (100\% women) working in the Independent Public Children's Teaching Hospital in Warsaw. The mean age was 49 years (mode and median: 50; min. 31, max. 61, $\mathrm{SD}=7.95$ ). The mean of the professional experience among the study group amounted to 30 years (mode: 25, median: 30, min. 17, max. 40, $\mathrm{SD}=6.38$ ). Eight nurses have graduated from medical secondary school, another eight nurses have graduated from first-cycle degree programme, and seven nurses have graduated from second-cycle degree programme. The largest number of respondents (17 persons) lived in a town with a population over 500,000 people, three persons lived in a town with a population between 100,000 and 500,000 people, one person lived in a town with a population below 100,000, and two persons lived in the country. Among the study group, specialisation programmes were completed by nine persons, qualifying courses - by seven persons, specialist courses - by two persons, and skills improvement courses - by one person. Additionally, one person graduated from postgraduate training in management. As many as 20 study participants worked in a hospital department as a departmental nurse and two persons worked in a specialist outpatient clinic as a senior nurse.

An original questionnaire divided into three parts constituted a research tool for the study. The first part consisted of 10 single-choice questions and aimed to check what respondents knew about the legal changes. The second part of the questionnaire comprised of 32 statements that were assessed according to a five-point Likert scale ( 1 - strongly disagree, 5 - strongly agree). The last part focused on self-assessment of the study group related to the issue in question: 10 statements were also assessed on a five-point Likert scale.

Owing to the fact that the present study was comprehensive (a small study group), i.e. it involved all departmental nurses of the Independent Public Children's Teaching Hospital in Warsaw, no statistical inference was conducted and only whole numbers were used to present the results.

\section{Method of assessment of questionnaire reliability}

An assessment of questionnaire reliability was performed on the basis of an internal consistency analysis conducted for the entire scale and for selected subscales by determining appropriate reliability coefficients in accordance with the Cronbach's formula. In compliance with the Nunnally criterion, the level of reliability was established at $\alpha>0.70$ [7]. An intercorrelation matrix was determined and consistency criterion was established at $r>0.10$ to estimate the interscale consistency of particular statements. The analysis of questionnaire reliability was conducted using Statistica Statsoft 12.0 program (licensed to the Medical University of Warsaw).

\section{RESULTS}

\section{Assessment of questionnaire reliability}

An assessment of questionnaire reliability was carried out on the basis of an analysis of the questionnaire part related to the attitudes of the study group towards extending professional powers of nurses due to the fact that they were assessed on a Likert scale. Cronbach's alpha coefficient used to assess the questionnaire reliability, amounted to 0.821 for the entire scale.

Analysis of knowledge and attitudes of departmental nurses

An analysis of respondents' answers to questions regarding their knowledge about the legal changes demonstrated that nearly half of them was correct. Almost all departmental nurses knew that independent prescription of certain medicines by nurses and midwives shall be their rights, not duties. A vast majority of the respondents also knew about the limitations concerning referring patients for diagnostic tests. In addition, over half of the study participants knew where to find the list of drugs to be prescribed by them independently. On the other hand, less than half of the departmental nurses knew when the new regulations shall enter into force and only every third nurse knew that the scope of new competences shall differ depending on the level of education of a nurse or midwife. A small proportion of the respondents knew criteria a nurse or midwife needs to meet in order to be allowed to refer patients for diagnostic tests. See Table 1 for detailed results concerning knowledge of departmental nurses.

A vast majority of departmental nurses believed that the new regulations shall improve patient care and increase patient comfort, reduce waiting times for medical advice and simplify the procedures of providing health services. The respondents also believed that their new powers would increase the control of nurses and midwives over the treatment process and most of them also believed that the prestige of both professions would be enhanced as well. On the other hand, according to a large proportion of departmental nurses, the legal changes would impose on them another obligation that so far had applied to doctors, and the range of professional and legal responsibility of nurses and midwives would increase. The respondents were also divided on whether the expanding of their powers is needed in Poland. See Table 2 for detailed results regarding opinions of departmental nurses about the influence of the Nurses and Midwives Act on the functioning of the healthcare system.

According to a vast majority of the departmental nurses, nurses and midwives should be entitled to prescribe certain medicaments, to issue prescriptions, and to independently refer patients for diagnostic tests. They were more sceptical about continuation of treatment under a medical order, but still there were more supporters than opponents of this solution among the respondents. On the other hand, more than half of the study participants said that nurses and midwives were not prepared to refer patients for tests, to continue treatment, and to give prescriptions. The respondents believed that nurses and midwives were better prepared for prescribing certain medicines. See Table 3 for detailed data.

The departmental nurses admitted that they were neither familiar with the introduced amendments, nor prepared for them and they would like to attend a training on new powers of nurses and midwives. They also believed that their salaries need 
TABLE 1. Knowledge of departmental nurses about expanding competences of nurses and midwives.

Question

1. Which Act has been amended with changes that expand the professional qualifications of nurses and midwives with reference to prescribing certain medicines and writing prescriptions?

2. When will the changes that expand the professional qualifications of nurses and midwives with reference to prescribing certain medicines and writing prescriptions come into force?

3. Will independent prescription of certain medicines and independent issuing of prescriptions be

4. Will each nurse and midwife be allowed to prescribe certain medicines and to issue prescriptions? the duty of nurses and midwives?

Answer

Number of answers

The Act of May 12, 2011 on the Reimbursement of Medicines, Foodstuffs Intended 2 for Particular Nutritional Uses and Medical Devices

Nurses and Midwives Act of July 15, 2011

10

Act of July 1, 2011 on Professional Self-Government of Nurses and Midwives, Nurses and Midwives Act of July 5, 1996,

I do not know

July 1, 2017

January 1, 2017

July 1,2016

January 1, 2016

I do not know

Yes

No

I do not know.

yes, each nurse and midwife

only nurses and midwives with a Master's degree

only nurses and midwives with a Master's degree who

also completed a specialist course in this field

only nurses and midwives with a Master's degree or specialisation

order" certain medicines and issue prescriptions for these drugs?

only nurses and midwives with a Bachelor's degree who completed a specialist course in this field as well and nurses and midwives with the right to prescribe medicines

6. Will each nurse and midwife be allowed

to refer patients for diagnostic tests independently?

nurses and midwives with a Master's degree who completed a specialist course in this field

I do not know

No, nurses and midwives will be allowed to refer patients for any diagnostic tests

7. Will the nurses' and midwives' right to refer patients for diagnostic tests be limited?

8. Changes in extending professional qualifications of nurses and midwives shall concern:

9. Nurses and midwives with a Bachelor's degree (first-cycle study) and Master's degree (secondcycle study) will have a different level of professional powers with respect to independent prescription of certain medicines and issuing prescriptions.

10. A list of medicines that nurses and midwives shall be entitled to prescribe on their own and to issue prescriptions for these drugs will be published in:

* - the correct answer is in bold who also completed a specialist course in this field

15

I do not know

yes, each nurse and midwife

only nurses and midwives with a Bachelor's degree

only nurses and midwives with a Bachelor's degree

who also completed a specialist course in this field

$$
\text { I do not know }
$$

yes, each nurse and midwife

only nurses and midwives with a Bachelor's degree

who also completed a specialist course in this field

nurses and midwives with a Bachelor's degree or a specialisation

Yes, nurses and midwives will be allowed to refer patients for diagnostic tests except for laboratory diagnosis

Yes, nurses and midwives will be allowed to refer patients for diagnostic tests except for high-risk diagnostic procedures

1

4

0

0

16

7

prescription of OTC drugs

0

prescription of reimbursed drugs

0

prescription of medicines, foodstuffs intended for particular nutritional uses and medical devices

9

prescription of medicines and medical devices under a medical order

I do not know

not know

Yes

8

No

7

I do not know.

8

Regulation of the Minister of Health
New Nurses and Midwives Act

Act amending the Nurses and Midwives Act

I do not know

16

2

4
I do not know 
TABLE 2. Opinions of departmental nurses about the impact of extending professional powers of nurses and midwives on the Polish healthcare system.

\begin{tabular}{|c|c|c|c|c|c|}
\hline & $\begin{array}{c}1 \\
\text { Strongly } \\
\text { disagree }\end{array}$ & $\begin{array}{c}2 \\
\text { Rather } \\
\text { disagree }\end{array}$ & $\begin{array}{c}3 \\
\text { No } \\
\text { opinion }\end{array}$ & $\begin{array}{c}4 \\
\text { Rather } \\
\text { agree }\end{array}$ & $\begin{array}{c}5 \\
\text { Strongly } \\
\text { agree }\end{array}$ \\
\hline $\begin{array}{l}\text { This will improve } \\
\text { patient care }\end{array}$ & 0 & 1 & 5 & 12 & 4 \\
\hline $\begin{array}{l}\text { This will increase } \\
\text { patient's comfort }\end{array}$ & 1 & 1 & 5 & 12 & 4 \\
\hline $\begin{array}{l}\text { This will facilitate access } \\
\text { to health care advice } \\
\text { for patients }\end{array}$ & 1 & 3 & 7 & 9 & 3 \\
\hline $\begin{array}{l}\text { This will reduce the } \\
\text { waiting time for treatment }\end{array}$ & 1 & 3 & 5 & 10 & 4 \\
\hline $\begin{array}{l}\text { This will save time } \\
\text { for a patient }\end{array}$ & 1 & 0 & 3 & 17 & 2 \\
\hline $\begin{array}{l}\text { This will save time } \\
\text { for a doctor }\end{array}$ & 0 & 2 & 5 & 9 & 6 \\
\hline $\begin{array}{l}\text { The new powers will be } \\
\text { just another duty of nurses } \\
\text { and midwives that had } \\
\text { applied only to doctors } \\
\text { so far }\end{array}$ & 1 & 2 & 5 & 9 & 5 \\
\hline $\begin{array}{l}\text { This will reduce } \\
\text { the quality of health care }\end{array}$ & 3 & 4 & 9 & 3 & 4 \\
\hline $\begin{array}{l}\text { This will increase } \\
\text { the number of medical } \\
\text { errors }\end{array}$ & 0 & 8 & 9 & 4 & 2 \\
\hline $\begin{array}{l}\text { The new powers will raise } \\
\text { the prestige of the nursing } \\
\text { and midwifery professions }\end{array}$ & 1 & 3 & 7 & 10 & 2 \\
\hline $\begin{array}{l}\text { The new powers will raise } \\
\text { legal liability of nurses } \\
\text { and midwives }\end{array}$ & 0 & 1 & 2 & 12 & 7 \\
\hline $\begin{array}{l}\text { The new powers will } \\
\text { lead to loss of control of } \\
\text { doctors over the treatment } \\
\text { process }\end{array}$ & 3 & 8 & 6 & 3 & 2 \\
\hline $\begin{array}{l}\text { The new powers will } \\
\text { increase control of nurses } \\
\text { and midwives over } \\
\text { the treatment process }\end{array}$ & 1 & 0 & 3 & 15 & 4 \\
\hline $\begin{array}{l}\text { The new powers will } \\
\text { simplify the process of } \\
\text { providing health care } \\
\text { services }\end{array}$ & 0 & 3 & 7 & 13 & 0 \\
\hline $\begin{array}{l}\text { The new powers will } \\
\text { disrupt the process of } \\
\text { providing health care } \\
\text { services }\end{array}$ & 3 & 6 & 11 & 1 & 2 \\
\hline $\begin{array}{l}\text { The new powers will lead } \\
\text { to a loss of patient confi- } \\
\text { dence in health } \\
\text { care protection }\end{array}$ & 2 & 7 & 7 & 3 & 2 \\
\hline $\begin{array}{l}\text { The new powers will im- } \\
\text { prove patients' confidence } \\
\text { in health care protection }\end{array}$ & 2 & 3 & 12 & 6 & 0 \\
\hline $\begin{array}{l}\text { The new powers are } \\
\text { needed in Poland }\end{array}$ & 1 & 1 & 12 & 8 & 1 \\
\hline
\end{tabular}

TABLE 3. Opinions of departmental nurses about appropriateness and preparation of nurses and midwives for extending their powers.

\begin{tabular}{|c|c|c|c|c|c|}
\hline & $\begin{array}{c}1 \\
\text { Strongly } \\
\text { disagree }\end{array}$ & $\begin{array}{c}2 \\
\text { Rather } \\
\text { disagree }\end{array}$ & $\begin{array}{c}3 \\
\text { No } \\
\text { opinion }\end{array}$ & $\begin{array}{c}4 \\
\text { Rather } \\
\text { agree }\end{array}$ & $\begin{array}{c}5 \\
\text { Strongly } \\
\text { agree }\end{array}$ \\
\hline $\begin{array}{l}\text { Nurses and midwives } \\
\text { should have the possibility } \\
\text { of prescribing certain } \\
\text { medicines }\end{array}$ & 1 & 2 & 2 & 13 & 4 \\
\hline $\begin{array}{l}\text { Nurses and midwives } \\
\text { should have the possibility } \\
\text { of issuing prescriptions }\end{array}$ & 2 & 2 & 5 & 12 & 2 \\
\hline $\begin{array}{l}\text { Nurses and midwives } \\
\text { should be able to } \\
\text { „re-order" medicines pre- } \\
\text { scribed earlier by a doctor }\end{array}$ & 2 & 5 & 5 & 7 & 4 \\
\hline $\begin{array}{l}\text { Nurses and midwives } \\
\text { should have the possibility } \\
\text { of referring patients } \\
\text { for diagnostic tests }\end{array}$ & 1 & 5 & 3 & 12 & 1 \\
\hline $\begin{array}{l}\text { Polish nurses and mid- } \\
\text { wives are prepared to } \\
\text { prescribe certain medicines }\end{array}$ & 5 & 6 & 9 & 3 & 0 \\
\hline $\begin{array}{l}\text { Polish nurses } \\
\text { and midwives are prepared } \\
\text { to issue prescriptions }\end{array}$ & 5 & 9 & 8 & 1 & 0 \\
\hline $\begin{array}{l}\text { Polish nurses and mid- } \\
\text { wives are prepared to } \\
\text { „re-order” medicines pre- } \\
\text { scribed earlier by a doctor }\end{array}$ & 6 & 8 & 6 & 2 & 0 \\
\hline $\begin{array}{l}\text { Polish nurses and midwives } \\
\text { are prepared to refer } \\
\text { patients for diagnostic tests }\end{array}$ & 5 & 7 & 9 & 2 & 0 \\
\hline
\end{tabular}

TABLE 4. Self-assessment on preparation of departmental nurses concerning the legal introduced changes.

\begin{tabular}{|c|c|c|c|c|c|}
\hline & $\begin{array}{c}1 \\
\text { Strongly } \\
\text { disagree }\end{array}$ & $\begin{array}{c}2 \\
\text { Rather } \\
\text { disagree }\end{array}$ & $\begin{array}{c}3 \\
\text { No } \\
\text { opinion }\end{array}$ & $\begin{array}{c}4 \\
\text { Rather } \\
\text { agree }\end{array}$ & $\begin{array}{c}5 \\
\text { Strongly } \\
\text { agree }\end{array}$ \\
\hline $\begin{array}{l}\text { I know the changes in law } \\
\text { concerning the extension } \\
\text { of the powers of nurses } \\
\text { and midwives }\end{array}$ & 2 & 15 & 3 & 3 & 0 \\
\hline $\begin{array}{l}\text { I am prepared for the new } \\
\text { regulations and changes } \\
\text { in law }\end{array}$ & 4 & 14 & 4 & 1 & 0 \\
\hline $\begin{array}{l}\text { I will take part in a special- } \\
\text { ist course preparing for the } \\
\text { extension of my powers }\end{array}$ & 1 & 4 & 6 & 9 & 3 \\
\hline $\begin{array}{l}\text { I would like to prescribe } \\
\text { certain medicines to } \\
\text { patients on my own }\end{array}$ & 4 & 8 & 5 & 5 & 1 \\
\hline $\begin{array}{l}\text { I would like to "re-order" } \\
\text { medicines to patients } \\
\text { on my own }\end{array}$ & 4 & 7 & 5 & 6 & 1 \\
\hline $\begin{array}{l}\text { I would like to refer } \\
\text { patients for diagnostic tests } \\
\text { on my own }\end{array}$ & 4 & 8 & 5 & 5 & 1 \\
\hline $\begin{array}{l}\text { I would like to keep } \\
\text { medical records in coop- } \\
\text { eration with a doctor }\end{array}$ & 4 & 10 & 3 & 5 & 1 \\
\hline $\begin{array}{l}\text { I believe that my earnings } \\
\text { should increase along } \\
\text { with the extension of my } \\
\text { responsibilities concerning } \\
\text { prescribing medicines }\end{array}$ & 0 & 2 & 2 & 7 & 12 \\
\hline $\begin{array}{l}\text { I need an additional training } \\
\text { on the changes in law con- } \\
\text { cerning the extension of the } \\
\text { nurses and midwives powers }\end{array}$ & 0 & 0 & 1 & 9 & 13 \\
\hline $\begin{array}{l}\text { I am not interested } \\
\text { in extension of my } \\
\text { existing powers }\end{array}$ & 6 & 8 & 2 & 4 & 3 \\
\hline
\end{tabular}


to increase with new entitlements. The departmental nurses were divided on whether to use their rights to issue prescriptions and refer for diagnostic tests or not. Most of them did not want to keep medical records in cooperation with a doctor, what seems to be necessary in new circumstances. See Table 4 for detailed data on self-assessment of the study participants.

\section{DISCUSSION}

The problem of nurses and midwives being allowed to give prescriptions and independently refer patients for diagnostic tests is a new issue in the Polish scientific literature. Since the powers in questions have not yet entered into force, no publications related to knowledge of and/or attitudes towards this issue among nursing managers were found in the Polish Medical Bibliography.

In the world literature (ProQuest, Google-scholar, PubMed, search dates: between April $1^{\text {st }}, 2001$ and April 1 $1^{\text {st }}$, 2015, language: English, key words: nurse prescribing, nurse prescribers) there were a number of publications relating to the assessment of the fact that nurses were given the power to write prescriptions and refer patients for diagnostic tests [2,6-9].

As far as present knowledge is concerned, the results allowed to conclude that the departmental nurses had insufficient knowledge of the upcoming legislative changes. This was also confirmed in the last part of the study where nurses admitted they were not familiar with the new regulations and needed training on the subject. It is positive that the departmental nurses at least knew the outline of the amendments and where to look for detailed information on the list of medicines to be prescribed by them independently.

The present study showed that departmental nurses believed that the changes will benefit patients. The present results correspond with a study by Gielen et al. [6]. A systematic review of 35 selected publications demonstrated that both objectively measured quality of care and patient satisfaction were higher (or at least comparable) in the case of nursing care rather than the one provided by physicians. No statistically significant differences were found between the number of referrals made by nurses and doctors. [6].

The departmental nurses were anxious about the increased liability when executing their new powers. Similar concerns were raised by R. Horton who analysed whether a nurse should bear the same responsibility if she/he prescribes the same drug as a doctor [7]. It seems that this issue is easy to solve in the Polish legal environment where the standard of due diligence is always individual: it is higher in the case of a professor in a clinic and lower in the case of a general practitioner. Indicating what level of medical knowledge can be required from nurses and midwives should not pose any problems.

In general, the departmental nurses were in favour of the changes introduced. They believed that nurses and midwives should have the right to prescribe certain drugs and refer patients for diagnostic tests. A qualitative study by Bradley and Nolan confirmed this thesis [8]. Respondents listed the following advantages of these entitlements: holistic approach to a patient, greater satisfaction with work, and work autonomy. According to nurses, these competences integrate their other obligations [8].

In addition, the present study demonstrated that departmental nurses believed representatives of their profession were not prepared to exercise their new powers. What is more, the respondents did not feel ready themselves. The present findings were not surprising. A meta-analysis by Latter and Courtenay showed that there are publications pointing to uncertainties related to diagnosis and insufficient knowledge of nurses issuing prescriptions [9]. Even more serious concerns were raised by Horton who concluded that nurses would need a course in pharmacology similar to the one physicians do in order to be able to exercise their powers effectively. The course should include, in particular, elements of pharmacokinetics, pharmacodynamics, and mechanisms of drug efficacy. Horton also cites a study by Leathard who said that the number of hours of pharmacology done by British nurses varies significantly, ranging between a few and one hundred hours. In addition, Horton concluded "a maiore ad minus" that if doctors keep making mistakes in prescribing medicines, other professional groups should not be granted such powers [7].

As mentioned in the introduction above, the right of nurses to write prescriptions and refer patients for diagnostic tests have been introduced to a number of healthcare systems. This was analysed by M. Krozen et al. They sent the questionnaire to 20 nursing associations, 20 medical associations and 20 government bodies from 10 countries: Australia, Canada, New Zealand, Finland, Sweden, Ireland, Holland, Spain, the UK, and the US. The return rate was $65 \%$, which was high (as many as $85 \%$ of nursing associations and as little as $35 \%$ of medical associations). One of the main issues examined in the questionnaire was the aim of introducing the powers in question. Most often the respondents mentioned the following aims: improvement of care quality, a solution to the problem of a shortage of medical staff and reaching patients in areas away from medical centres. In addition, nursing associations and government bodies added to the above list a better use of nurses' skills. All groups mentioned the aspect of legitimation of an existing practice (doctors signing documents filled in by nurses). Only a small number of respondents said that the aim of the entire amendment was to relieve doctors.

Krozen et al. also analysed the criteria nurses need to meet in order to get permission to write prescriptions as well as limitations associated with the issue. In most countries it is necessary to have a Master's degree in advanced nursing practice to obtain the right to prescribe medications. In some countries nurses acquire these rights by another kind of education - e.g. in Sweden it is a part of a specialisation training in primary health care. However, education is not always the only condition. In Finland, Ireland and the UK clinical experience of at least three years is necessary. Sometimes patient age constitutes a limitation, e.g. in Finland nurses cannot issue prescriptions to children. [2]

To conclude, extending the powers of nurses and midwives related to issuing prescriptions and referring patients for diagnostic tests was controversial in most countries where the change was introduced. Therefore, it should not come as a surprise that nursing managers were reluctant to the amendment of the Nurses and Midwives Act, particularly in relation to the readiness of nurses and midwives to exercise their new powers.

\section{Limitations of the present study}

The fact that only a small number of nurses of a particular profile (departmental nurses) participated in the study constitutes a limitation of the present results. In addition, all respondents worked in a paediatric teaching hospital. Hence, the study 
results cannot be considered as representative. It is only a pilot constituting an introduction to a representative quantitative study conducted among a representative group of nurses, with special reference to the level of education and place of work, particularly in outpatient clinics.

\section{Further directions of studies:}

The research will be continued among a representative and more diverse group of nurses and midwives as well as among students of nursing, midwifery, medicine, and public health since, in the future, these groups of students will be, directly or indirectly, beneficiaries of the amendments and they need to be trained in this field.

\section{CONCLUSIONS}

1. A questionnaire developed by the authors proved to be a reliable research tool and may be used in further studies on the knowledge of and attitudes towards new competences among nurses.

2. The level of knowledge of the study group of departmental nurses about the new competences was insufficient and requires supplementing. Therefore, increased educational efforts in this regard should be taken, particularly when the study participants reported their willingness to take part in such courses.

3. The attitudes of the study group of departmental nurses towards the new competences were not unambiguous. It should, however, be noted that the study was conducted in a specialised children's teaching hospital, where the application of the amended regulations, for objective reasons, shall be limited.

4. Although the nursing management staff supports the legislative changes, they object to the process of introducing them. This applies particularly to the necessity of an adequate preparation of nurses and midwives for the new services as well as increased professional responsibility and liability.

5. The study should be continued among a representative group of nurses with a similar level of education, professional experience, and place of work, with a particular consideration of nurses working in the outpatient health care.

\section{REFERENCES}

1. Klain T, Kaplan L. Prescribing competences of Advanced Practice Registered Nurses. J Nurs PracT. 2010;6:115-22.

2. Krozen M, Francke A, Groenewegen P, Van Dijk L. Nurse prescribing of medicines in Western European and Anglo-Saxon countries: A survey on forces, conditions and jurisdictional control. Int J Nurs Stud. 2012;49:1002-12.

3. Ustawa o zawodach pielęgniarki i położnej z dnia 15 lipca 2011; Dz. U. z 2011 r. Nr 174, Poz. 1039, ze zm. [http://isap.sejm.gov.pl/Download;jses sionid=021B0102E9F1F9A6D967F2DF2ABF992D?id=WDU201117410 39\&type=3 data dostępu: 6-04-2015]

4. Projekt Ustawy o zmianie ustawy o zawodach pielęgniarki i położnej wraz z projektem Rozporządzenia wykonawczego: [http://orka.sejm.gov. pl/Druki7ka.nsf/0/EF316A39A8394B06C1257B6B004792B2/\%24Fi le/1354.pdf data dostępu: 30-03-2015]

5. Nunnally JC, Bernstein IH. Psychometric theory. 3 ed. New York: McGraw-Hill New York; 1967.

6. Gielen S, Dekker J, Francke A, et al. The Effects of nurse prescribing: A systematic review. Int J Nurs Stud. 2014;51:1048-61.

7. Horton R. Nurse-prescribing in the UK: Right but also wrong. The Lancet. 2002;359:1875-6.

8. Bradley E, Nolan P. Impact of nurse prescribing: a qualitative study. J Adv Nurs. 2007;59:120-8.

9. Latter S, Courtenay M. Effectiveness of nurse prescribing: a review of the literature. Issues Clin Nurs. 2004;13:26-32.

\section{Corresponding author}

Dr hab. n. o zdr. Joanna Gotlib

81 Żwirki i Wigury Str., 02-091 Warszawa

E-mail: joanna.gotlib@wum.edu.pl 